\title{
International symposium on trichomoniasis: the Polish medical scene
}

\author{
R D CATTERALL* \\ From the Department of Genitourinary Medicine, Middlesex Hospital, London
}

\begin{abstract}
The sixth International Congress of Protozoology was held in Warsaw from 5-11 July 1981. A satellite international symposium on trichomoniasis was held in Bialystok, a small industrial and university town in north-east Poland, from 13-15 July 1981. The symposium was organised by Professor Stefan Soszka, professor of obstetrics and gynaecology at the Medical Academy of Bialystok, Professor Bronislaw Honigberg, professor of protozoology at the University of Massachusetts, Amhurst, USA, and Professor Miklos Müller, of the Rockefeller University, New York, USA.
\end{abstract}

\section{International symposium on trichomoniasis}

The opening ceremony took place in the Aula of the Medical Academy, which is housed in a beautiful 18 th century château. Both the château, which was virtually undamaged during the second world war, and the extensive gardens have been maintained in excellent condition.

The delegates were welcomed by the dean of the Medical Academy and by Professor Stefan Soszka, who said how pleased he was to see so many doctors and scientists from Eastern Europe, Western Europe, and North America. Dr R D Catterall (London), president of the International Union against the Venereal Diseases and Treponematoses (IUVDT) and the official representative of the World Health Organisation, pointed out that a great deal of excellent scientific and clinical work had been carried out on trichomoniasis by workers in Eastern Europe. He expressed the gratitude of the delegates to the commission on trichomoniasis of the General Council of the Polish Parasitological Society and the Medical Academy in Bialystok for arranging the symposium in such beautiful surroundings and for their generous hospitality.

\footnotetext{
${ }^{*}$ President, IUVDT

Address for reprints: $\operatorname{Dr}$ R D Catterall, Department of Genitourinary Medicine, Middlesex Hospital, London W1N 8AA

Accepted for publication 18 August 1981
}

SCIENTIFIC AND CLINICAL PAPERS

At the first session Professor Bronislaw Honigber gave a detailed paper on the fine structure of Trichomonas vaginalis in relation to other trichomonads and Professor Miklos Müller reviewed the present state of knowledge of the functionat morphology of Trichomonas vaginalis. After a lively discussion it was agreed that Trichomonas vaginalis is a phagocytic organism. Most of the ingesteft bacteria are destroyed in vacuoles within 15 to $2 \theta$ minutes and experimental evidence shows that the is also direct killing of gonococci by trichomonads -

Professor Juri Teras (USSR) claimed to hav\& isolated Trichomonas vaginalis from the bronchi an $\mathbb{A P}^{\mathrm{P}}$ bronchial secretions of 80 out of 400 patients Agglutination reactions were also positive in man cases and specific antibodies were detected in the ser of several patients. The role of orogenital sex in thi finding was discussed and the question of whethe Trichomonas vaginalis or other trichomonads actually cause respiratory disease was debated during the discussion. Many of the delegates expressed doubt about the interpretation of the findings.

Several papers describing the biomorphology of round, multinucleated forms of Trichomonas vaginalis led to a detailed discussion about rounc cyst-like forms so frequently described by French workers. Strong doubts were expressed whether these round structures were really forms of Trichomonas vaginalis and there was scepticism about whethe they ever developed into motile, flagellated pathogenic forms either in vitro or in vivo.

Understanding of the metabolism of Trichomonas vaginalis has advanced considerably in recent years The subject was fully reviewed by Dr David Linsteo (England) and the mechanism of the development of resistance to metronidazole discussed. Trichomonas vaginalis is regarded as an aero-tolerant anaerobe bufe its redox carriers are readily destroyed by oxygen ${ }_{\circledast}$ The hydrosome was thought to play an important role in metronidazole resistance.

A complete review of the present state of the immunology and serology of human trichomoniasis was presented by Dr John Ackers (London). The rolę 
of polymorphonuclear leucocytes in killing Trichomonas vaginalis and the importance of complement and $\mathrm{C} 3$ were considered and the production of local antibodies described. Dr R D Catterall (London) reviewed recent work on the epidemiology and diagnosis of human trichomoniasis from a clinical standpoint and Dr Michael Spence (Baltimore, USA) described the association of Trichomonas vaginalis and other sexually transmitted organisms in human genital infections.

FUTURE AREAS OF RESEARCH

The large number of papers on various experimental and clinical aspects of human trichomoniasis indicated the interest still taken in the subject, and it was agreed that many problems remained to be solved. These included: important aspects of the metabolism of Trichomonas vaginalis and other trichomonads; the reasons for the continuing high prevalence of infection throughout the world, despite effective curative treatment; the failure to detect the protozoon in the male sexual partners of infected women in most cases; the possible existence of rounded cyst-like forms and their clinical significance; and the development of resistance to trichomonacidal drugs. Trichomonas vaginalis provides a very satisfactory model for the study of other protozoa, especially their biochemistry and metabolism, and there are several areas where useful future research work is indicated.

It was suggested that the next international symposium on trichomoniasis should be held in Prague in 1983.

\section{The Polish medical scene}

Polish doctors base their practices on Western European, British, and North American medicine. Most specialised textbooks are in English, however, and keeping up to date with modern developments is difficult, since there are very few medical visitors from the West, and foreign medical journals are scarce and expensive. Although permission may be obtained to attend international meetings abroad, only one delegate from Poland is usually sent because of expense.

Health care is free for everyone in communist states in Eastern Europe and is based on hospitals much more than in the United Kingdom. The amount of care available to patients is rationed by the size and sophistication of the district hospitals and the scope of the services available in the teaching hospitals and main centres in Warsaw.
SERVICES FOR STDS

The service for patients with sexually transmitted diseases is undertaken by the department of dermatovenereology at the various hospital centres, as is traditional in European countries. At the Medical Academy in Warsaw, however, dermatology and venereology are separated. The Institute of Venereal Diseases is housed in the same building as the department of dermatology but is an independent unit. It is largely the brain-child of Professor Josef Towpik, who is well known to members of the International Union against the Venereal Diseases and Treponematoses and who took an active part in the travelling seminar which visited the United States in 1971. He has been a member of several scientific groups of the World Health Organisation and was recently the president of the Polish Medical Association; he has now retired from medical practice. His successor as head of the Institute of Venereal Diseases of the Warsaw Medical Academy is Dr Tomasz Mroczkowski.

The institute occupies part of an old hospital building with spacious lofty rooms. There is both an outpatient section and beds in the wards. Patients with STDs wait in the corridors together with those with skin diseases, and there is no appointment system. The staff have regular clinical meetings and discussions.

The venereological laboratories are some distance away from the institute and are directed by a microbiologist, associate professor $\mathrm{Dr}$ Danuth Weyman-Rzucidto. Roiron's medium is used for cultures for gonorrhoea, and Roiron's TV medium for growing Trichomonas vaginalis, and Sabouraud's medium for Candida; a culture service for Chlamydia trachomatis has just been started.

The routine serological tests for syphilis performed on all sera are the Venereal Disease Research Laboratory (VDRL) and fluorescent treponemal antibody-absorption (FTA-ABS) tests. In patients showing a positive result an IgM-FTA test is usually performed. The Treponema pallidum haemagglutination assay (TPHA) is also available, and the $T$ pallidum immobilisation (TPI) test is sometimes performed in difficult cases.

The overall impression was of an active keen unit with high standards of patient care.

SOCIAL AND POLITICAL LIFE

It is very evident that the church is still the focal point of Polish life despite 35 years of rigid communist rule. The visit of Pope John Paul in 1979 brought about spontaneous mass meetings all over the country and was a major factor in the rapid and astonishing growth of the trade union Solidarity. Its 
impact can be seen everywhere in the form of signs, posters, display cases, and lapel badges. In the hospitals, in public buildings, and in the market places literature about free trade unions is openly displayed all over the country. Television programmes are remarkably outspoken and present the aims of Solidarity to the nation.

The principal objective of Solidarity is a Polish government which is responsive to the wishes of the people. In the health service its aims are to eliminate political influence in recruitment, to improve the medical curriculum, and to have a less rigid academic structure. Many Poles apparently remain communists but do not wish to see the continuation of the rigid Soviet-type leadership.

There are, however, serious shortages all over the country. Food is scarce and certain medicines and drugs unobtainable. Queues exist everywhere and are getting worse. The shops are empty of goods but the people still look well nourished and well dressed.

\section{THE FUTURE}

The country is bubbling with expectation and guardee optimism. People are very friendly to foreigners and want to talk; above all they want moral and persona. support from the West. Personal relationships are very important to them and they are eager for contact with foreigners. Medical journals and books ar highly prized and clinical exchanges and fellowships greatly appreciated, as are visits to Poland by Western doctors. In the face of mounting difficulties? due to shortages in the hospitals, Polish doctors areir faced with a testing time ahead and need the suppore of the profession everywhere in the world. 